\title{
God se antwoord op geweld en land in Deuteronomium
}

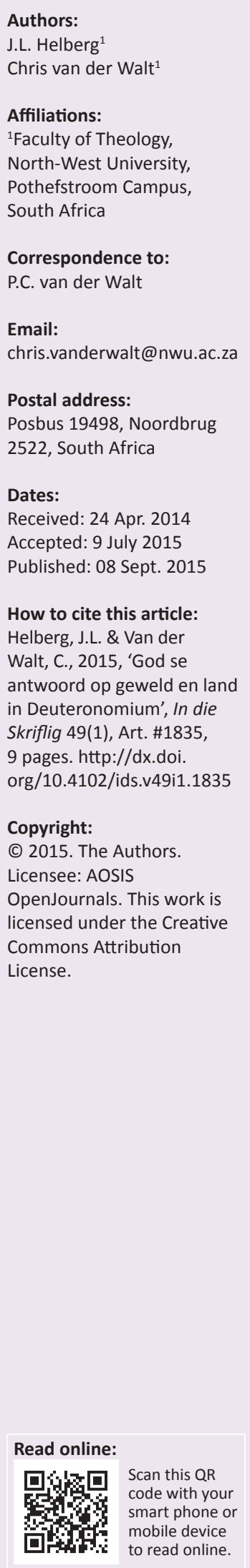

Deuteronomium getuig van God se besondere liefde soos Hy dit in verband met die Beloofde Land aan Israel betoon het. Sy bevoorregting van Israel asook sy betrokkenheid by geweld roep egter baie vrae en bespreking op. Twee aspekte wat nie in die besprekings daarvan werklik aandag kry nie, word in hierdie artikel ondersoek: enersyds die verantwoordelikheid en/of skuld van die menslike partye en andersyds dié van God. Die bevindinge is: (1) Nie die nasies of Israel kan God verwyt nie, want die nasies tree self gewelddadig en eksploiterend teenoor mekaar op. Mense bewoon die aarde ten koste van ander mense en ook ten koste van die aarde self. Hulle tree hardnekkig en opstandig op teen die Wet en die wil van God wat die beste vir hulle bedoel. Tog is God in beheer van alles wat gebeur, Hy is onbegryplik en sonder blaam, selfs wanneer Hy in en deur die sondige werklikheid optree. (2) Deuteronomium praat van God se krasse geweld én oorweldigende liefde en verkondig dat Hy die verantwoordelikheid en skuld van die sondige, opstandige mensdom op Hom neem. Hierop gee die Dienaarliedere van Jesaja nog duideliker lig. God moet veral teen hierdie positiewe getuienis waardeer word. Dit is Hy wat aan die werk is en daarom moet die situasie vanuit die oogpunt soos Hy Homself bekend maak, beoordeel word.

God, violence, and land in Deuteronomy. Deuteronomy attests of God's exceptional love as proven to Israel in connection with the Promised Land. However, his preferential treatment of Israel and his involvement in violence invokes many questions and much debate. This article investigates two aspects, which do not really receive attention in the debate: on the one hand, human responsibility and guilt, and on the other hand that of God. The findings are: (1) Neither the nations nor Israel can reproach God, for they themselves act violently and exploitingly. They inhabit the earth at the expense of others and of the earth itself. They act obstinately toward the Law and the will of God, who has the best in mind for them. Even so, God is without blame, incomprehensibly in control of all that happens, even when he acts in and through the use of the sinful reality. (2) Deuteronomy testifies about God's severe violence and overpowering love. It is implicitly stated that God takes the responsibility and blame of sinful and rebellious humanity upon himself. The servant songs of Isaiah shed even more light on this issue. God must especially be appreciated by these positive testimonies and with complete trust in his unfathomable power and grace.

\section{Vertrekpunt}

In hierdie artikel word daar uitgegaan van die vertrekpunt dat die finale teks van die Ou Testament, soos dit deur die Christelike geloofsgemeenskap as kanon ontvang is, God openbaar en dat die boeke onder bespreking teen die groter konteks van die kanon gelees moet word wat in sigself koherensie het (Barrett 2009).

\section{Inleiding}

Daar is tans heelwat emosionele belewenis in Suid-Afrika aangaande grondbesit. Daar word selfs gedreig met gewelddadige grondbesetting, of dit word inderdaad met geweld gedoen. Die vlaag van xenofobiese geweld was met die skryf van hierdie artikel (April 2015) ook sodanig dat dit wêreldwyd die nuushooftrekke gehaal het (Karimi 2015). Die werklikheid van geweld is ook 'n onderwerp wat in die Bybel wetenskaplike gesprek aangetref word. Meyer (2011) vra byvoorbeeld die volgende vraag:

The crucial question that needs to be addressed is whether the Bible, and especially the Old Testament, is part of the problem or part of the solution. The Old Testament is clearly a violent book. How do we deal with this? (p. 1)

Die fokus van hierdie artikel is om 'n bydrae te lewer tot die beantwoording van daardie vraag. 
Alhoewel Deuteronomium getuig van God se besondere liefde wat Hy aan Israel betoon het deur hulle die beloofde land te gee, roep sy bevoorregting van Israel en goedkeuring van geweld teen Israel se vyande by die vestiging in die land (Deut $2: 34 ; 3: 6 ; 7: 24),{ }^{1}$ baie vrae op. God se gewelddadige optrede is egter nie beperk tot diegene buite Israel nie, want selfs in sy verhouding met sy eie volk, word Hy as 'n verterende vuur geteken. Die doodstraf vir afgodedienaars en die feit dat mense met klippe doodgegooi is oor iets soos buite-egtelike geslagsgemeenskap, vergestalt hierdie siening $(4: 24 ; 9: 3 ; 13: 10 ; 17: 5 ; 22: 21-24)$.

Op twee aspekte hiervan sal voorts lig gewerp word. Enersyds die verantwoordelikheid en/of skuld van die menslike partye, en andersyds dié van God.

\section{Land in die Ou Testament}

Die verhouding tussen die mens en land is ' $n$ prominente tema wat in die Ou Testament voorkom. Dit is egter nie net die land en sy bewoners wat ter sprake is nie. Land het dwarsdeur die Ou Testament ' $n$ baie belangrike betekenis in verband met God se heerskappy en die erkenning daarvan. ${ }^{2}$ Reeds in Genesis word dit duidelik dat land belangrik is as bestaansruimte vir die mens, aangesien die mens met sy skepping in so 'n bestaansruimte in die Tuin van Eden geplaas is (Gen 2:8). Die mens se aanvanklike bestaansruimte is egter nie net tot Eden beperk nie, omdat God aan hulle die opdrag gegee het om die aarde (הָאָרץ ) te vul en te onderwerp (Gen 1:28). Dat met hier die hele aarde bedoel word en nie net 'n gelokaliseerde deel daarvan nie, kan duidelik uit die konteks afgelei word omdat die visse, voëls en al die diere by die opdrag ingesluit is.

As verteenwoordiger en beeld van God kon die mens 'n kind-ouerverhouding met Hom beoefen (Firth \& Johnston 2012:34). Die mens het daarom alle rede gehad om dankbaar te wees vir God se liggaamlike en geestelike sorg en om volle vertroue te hê dat God die beste vir hom bedoel. Tog was hy ten volle op homself en sy eiebelang gerig en het hy hom deur die slang laat verlei om self oor sy lewe en optrede te beslis (Gen 3). Die mens het hom dus nie gesteur aan die wil en opdrag van God en aan die waarskuwing oor die dood as straf op ongehoorsaamheid nie. Dié strafdreiging het ná die mens se ongehoorsaamheid 'n werklikheid geword. Tog het God die mens nie dadelik laat dood neerslaan nie. Wat wel gevolg het, is dat die mens na die sondeval, van God en sy medemens vervreemd geraak het. Hy het egter ook van sy gegewe bestaansruimte vervreemd geraak toe

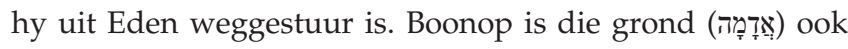
vervloek, wat beteken dat voorsiening in lewensbehoeftes voortaan drasties ingekort sou wees, en selfs opgeskort kon word (Gordon 1998:524). Waar die mens voorheen volledige versorging van God kon verwag, sou dit voortaan deur

1.Verdere verwysings na Deuteronomium sal slegs met hoofstukke en verse aangedu word.

2.Vir uitvoerige bespreking kan die volgende twee bronne geraadpleeg word: Frankel (2011) en Helberg (1990) moeisame selfvoorsiening moes gebeur deur bewerking van die grond (Gen 3:17).

Daar het dus vervreemding tussen God, wat die lewe is, en die mens ingetree en daarmee saam disharmonie met die hele skepping en alle skepsels (Fee \& Hubbard 2011:81). Desnieteenstaande die feit dat dood, disharmonie en lyding nou die menslike bestaan gekenmerk het, was daar tog ook voortgang en lewe. Daarvan getuig die herhalende patroon wat in die geslagsregister in Genesis 5 aangetref word, naamlik dat van die een na die ander mens gesê word hy het 'gelewe ... en hy het gesterwe'. Hierdie patroon sou hom in die res van die mens se bestaan herhaal soos deur die sondvloed bevestig word. Daar was ook dood, maar deur God se inisiatief ook lewe, wat Hy op 'n 'vreemde manier' deur die ark bewerk het. God se optrede in verband met die sondvloed lyk ook inkonsekwent as Hy dieselfde motivering gee vir vernietiging van lewe asook die voortsetting daarvan. In Genesis 6 staan:

Toe die Here sien hoe groot die verdorwenheid van die mens op aarde is en dat hy sy lewe lank net slegte dinge bedink, was die Here bedroef daaroor dat Hy die mens op die aarde gemaak het. Dit het Hom diep gegrief. Die Here het gesê: 'Ek sal die mens wat Ek geskep het, wegvee van die aarde af' ... Maar Noag is deur die Here begenadig. (v. 5-8 [kursief-outeur $]$ )

\section{Later in Genesis 8 lees ons die volgende:}

Toe het Noag 'n altaar vir die Here gebou en van al die rein vee en die rein voëls gevat en brandoffers op die altaar gebring. Die Here het die offer aanvaar en Hy het by Homself gesê: 'Ek sal nie weer so 'n ramp oor die aarde laat kom vanweë die mens nie. Van sy jeug af bedink die mens net slegte dinge, maar Ek sal nie weer al wat lewe laat omkom soos Ek gedoen het nie'. (v. 20, 21 [kursief-outeur])

Deur bostaande twee gedeeltes so direk langs mekaar te beskou, word dit duidelik dat God se optrede nie maar op 'n eenvoudige manier waardeer kan word nie, aangesien daar meer in sy optrede lê as wat direk voor die hand liggend is.

Wanneer die mens ná sy begenadiging in die sondvloed tog weer sy rug op God keer deur op eie prestasie staat te maak en nie te fokus op 'n persoonlike band met God nie, maar op ' $n$ onpersoonlike band met die stad Babel, beantwoord God hulle optrede deur hulle onderling te vervreem en te verstrooi (Helberg 2011:54). In slegs die volgende hoofstuk van Genesis maak God egter weer 'n nuwe begin met die mensdom deur sy roeping van Abram. In plaas daarvan om die mens as verdryfdes uit hulle lewensruimte te behandel, beloof Hy 'n land aan Abram en sy nageslag (Gen 12, 15). Hierdie gebeurtenis is soos lewewekking uit dood.

Ten spyte van die belofte wat Abram ontvang dat hy en sy nageslag die land sal besit (Gen 15:7, 18), val dit op dat die land nooit 'die land van Abraham' genoem word nie. Telkens wanneer daar in Deuteronomium van 'land' en 'Abraham' in dieselfde konteks gepraat word, word dit in verband met die belofte wat God gemaak het, gebring. Die beloofde land is dus heeltemal God se inisiatief en uitvoering. Daarom gaan 
dit nie om die land of Abraham of die volk of ander volke se belange nie, maar om God self. Sy weg met Abraham is die vrug van verbond en verkiesing en is eksklusief; dit geld alleen vir Israel (Helberg 2011:35). Tog is dit ook die middel om (uiteindelik) die ander wat ook van God vervreem is, in te sluit.

Die welsyn van die mensdom rus dus in die verhouding tussen God en Abraham met wie God 'n verbondsverhouding aangaan (Helberg 2011:54-56). Tog het die mensdom 'n fisiese bestaansruimte nodig waarbinne daardie verhouding prakties tereg kan kom. Frankel (2011:72-73) praat van 'n spanning tussen 'n 'land-centered' en 'n 'covenant-centered' benadering deur God. Die land, soos wat God dit aan Abraham belowe het, is daarom, as bestaansruimte, primêr bedoel as ruimte waar God binne die raamwerk van sy Wet gedien moet word (5:1-6). Samehangend hiermee word daar in Deuteronomium 'n teologiese diepteperspektief aangetref waaroor Longman and Dillard (2010) die volgende opmerking maak:

Deuteronomy is far more capable of a depth and subtlety in its theological reasoning than modern scholars have been prone to recognize ... the tension between law and grace is an essential ingredient in Deuteronomy. (p. 118)

Saamgevat: Reeds in die begin word dit duidelik dat God land aan die mens gee as bestaansruimte. As gevolg van die eiewilligheid van die mens, word hy egter vervreem, nie net van God en sy medemens nie, maar ook van sy bestaansruimte. Ten spyte van hierdie vervreemding is daar egter tog, op inisiatief van God, voortgang en lewe in die sin dat Hy met ' $n$ individu, Abram, 'n verbond sluit wat nie net weer vir hóm 'n bestaanruimte belowe nie, maar ook 'n bestaansruimte vir sy nageslag. In Abraham word daar selfs 'n seën aan al die volke van die aarde toegesê (Gen 12:3). Dié bestaanruimte word egter belowe nie bloot ter wille van die mens se voortbestaan nie, maar ter wille van ' $n$ ruimte waar 'n verhouding met God moontlik is.

\section{Die agtergrond van die boek Deuteronomium}

Deuteronomium beskryf in hoofsaak die toesprake van Moses op die vlakte van Moab. Dit herinner Israel daaraan dat die land 'n geskenk van God is $(6: 10,11)$, dat dit 'n goeie land is, maar tegelyk ook 'n land waar Israel versoek sal word om te vergeet dat hulle die land as geskenk van God gekry het (Vannoy 1988:1306).

Volgens die eerste hoofstukke van Deuteronomium kyk Moses terug na die mislukkings van die volk in die verlede, maar lei hy Israel ook tot verbondshernuwing voordat hulle toetree tot die oorloë waardeur hulle die beloofde land in besit sou neem. Alhoewel die boek Deuteronomium bogenoemde agtergrond het, is dit waarskynlik een van die belangrikste boeke van die hele Ou Testament. Dit is die hoogtepunt van die Pentateug, maar met sy karakteristieke teologiese perspektief beïnvloed dit nie net die res van die historiese stof in die Ou Testament nie, maar selfs ook die profete, onder andere die boek Jesaja (Lundbom 2013:35).

\section{Die doel van Deuteronomium}

Deuteronomium is struktureel geskoei op die elemente van die Ou Nabye Oosterse verdrae. Hierin word God as die Suserein en Israel as die vasaal voorgestel. Indien die volk die stipulasies van die verbond sou gehoorsaam, sou dit vir hulle lewe beteken terwyl ongehoorsaamheid tot dood sou lei (McConville 1998:747). Teen hierdie agtergrond gesien, verduidelik Clements (2001:1) dat Deuteronomium die bedoeling het om die verbond met die nuwe geslag te hernu en te formaliseer. Dit word gedoen ter voorbereiding om die beloofde land in te neem. Daar word ook in Deuteronomium baie klem geplaas op die land waar die volk ná hulle intog, die wet van die Here moes onderhou.

Von Rad (1962:231; 1968:17-21) oorbeklemtoon egter die voorwaardelike karakter van die besit van die land, asof die nakoming van die gebooie in 'n absolute sin 'n vereiste daarvoor was. Deuteronomium 30 gee egter ander lig daarop:

Die Here jou God sal jou lewe en die lewe van jou nageslag aan Hom wy, sodat jy Hom sal liefhê met hart en siel ... Dan sal jy terugkom na die Here en Hom gehoorsaam en volgens al sy gebooie lewe wat Ek jou vandag beveel. (v. 6-8)

Die eis om gehoorsaamheid rus dus in werklikheid op 'n reeds bestaande verhouding tussen God en Israel wat uitgedruk word in die selfbekendstelling 'Ek is Jahwe jou God', waarmee die afkondiging van die gebooie ingelei word (5:6), en verder in die besonder oorvloedige gebruik van die uitdrukking 'Jahwe jou/julle/ons God'. ${ }^{3}$

Hy is die enigste God, daar is geen ander nie; Hy is ook die enige God, nie meervoudig nie, maar geïntegreerd en daarom eis Hy om liefgehê en gedien te word met hart en siel, as eenheid, met algehele oorgawe en volle vertroue, nie halfhartig of dubbelslagtig, met een oog op die afgode van die magtige nasies nie, maar geïntegreerd volgens sy wil in sy Wet.

God is ook allesbeheersend, tree wonderdadig, vrymagtig en met inisiatief op, en is aan niemand verantwoording verskuldig nie. Hy is ook die regverdige (32:1-4) en in sy geregtigheid is Hy soos 'n verterende vuur (32:22) en daarom betrokke by gewelddadigheid in so 'n mate dat dit vir die moderne mens ' $n$ ernstige probleem vorm. Om die probleem van geweld te probeer oplos gaan Bybelkritici op verskeie maniere met die teks om. Meyer (2011) gee hiervan ' $n$ breedvoerige samevatting en verduideliking in sy bespreking van die werk van Regina Schwartz, Jan Assmann en Gerlinda Baumann. In sy artikel wys hy daarop dat Bybelkritici die geweldsaspek op verskillende wyses hanteer deur verswyging, rasionalisasie of die vervanging daarvan met Nuwe-Testamentiese beelde van God se liefde. Daar word selfs voorstelle gemaak dat die Bybel herskryf moet word. Meyer wys in sy konklusie daarop dat Bybellesers die Bybel meer verantwoordelik moet lees en dan op so 'n wyse dat dit nie tot meer geweld aanleiding moet gee nie.

3.Vergelyk ook Eksodus 19:5-6 waar die vereiste om die verbond te hou, ingebed is in die feit dat God Israel na Hom toe gebring het. 
Die wyse waarop die teks verantwoordelik gelees moet word, is egter nie om op die antieke skrywers en identiteitsvorming te konsentreer nie, maar op die persoon om wie dit gaan en dit is God self. Die teks van die Ou Testament werp lig daarop deur God voor te stel as tegelyk die ontfermende en liefdevolle God, maar ook God wat straf en vernietig. Die inleiding tot die Tien Gebooie maak beide hiervan duidelik deur enersyds God se reddende optrede uit Egipte voorop te stel, maar andersyds ook die geweld teenoor Egipte waarmee dit gepaard gegaan het.

Die fundering vir hierdie optrede van God word aan die begin van die boek Deuteronomium gestel waar die saak van vertroue in die almag en vrymag van God na vore kom (1:32). Dit word hanteer in die lig van Israel wat betig word omdat hulle nie volle vertroue in God se almag en vrymag gehad het nie. Hulle het naamlik nie aan sy opdrag om die beloofde land in besit te neem, uitvoering gegee nie, en as rede aangevoer dat die bewoners groter en sterker as hulle is (1:26-28). Hulle het ook daardie nasies se afgode aangehang. God verafsku hierdie optrede en straf dit streng. So verkondig 4:3 'Julle eie oë het gesien wat die Here by BaälPeor gedoen het: elkeen wat vir Baäl-Peor gedien het, is deur die Here julle God tussen julle uit verdelg.' In hoofstuk 7 kom meer as straf egter na vore:

Weet dan nou: die Here jou God, Hy is God. Hy is die betroubare God wat sy verbond in stand hou en sy troue liefde betoon tot aan die duisendste geslag van hulle wat Hom liefhet en sy gebooie gehoorsaam, maar Hy straf elkeen wat Hom haat, Hy bring hom om, Hy laat nie na om elkeen wat Hom haat, te straf nie. (v. 9, 10; vgl. verder ook 11:26-28; 13:5; $28: 13$ e.v.; 30:17-18)

Hierdie gedeeltes wys dat Deuteronomium nie 'n naïewe godsdiens verkondig nie, maar die aardse bestaan teken as 'n onontvlugbare werklikheid van totale vervreemding. ${ }^{4}$ Die vervreemding geld vir die verhouding met mense, die land en selfs die aarde en God. Die vervreemding staan in skerp teenstelling met seën en voorspoed, soos vergestalt in 'melk en heuning, wingerde, olyfboorde (4:34; 6:3, 10-11) koring, wyn, olie, aanteel van grootvee en kleinvee en vrugbaarheid' $(7: 13,14)$.

God se optrede wys dus dat Hy nie partydig is nie, maar tog kies Hy een volk uit! Verder ontferm Hy Hom oor'n weduwee, weeskind en vreemdeling, terwyl hulle in werklikheid nog die veronregte groep is $(10: 18,19)$. Hier is dieselfde probleem as dié waarmee psalmdigters worstel: die werklikheid lyk so anders as die belofte van God (Ps 73). Psalm 1:1, as inleiding tot die psalmbundel, antwoord hierop dat ' $n$ mens jou nie deur die skyn van die werklikheid moet laat mislei en jou heil in iets anders as die Woord van God met sy beloftes moet soek nie (Miller 1986:83-84). Volgens sowel die Psalmboek as Deuteronomium, maak die teenwoordigheid van God egter 'n wesenlike verskil.

4.Deuteronomium gooi nie bloot die landkwessie oor die boeg van die vervloekte aarde (Gen 3:17) nie, maar beklemtoon Israel en die nasies se kontemporêre aarde Gen 3:17) nie, maar beklemtoon Israel en die nasies se kontemporere God het by Horeb 'n verbond met ons gesluit. Dit is nie ons voorvaders met wie Hy God het by Horeb ' $n$ verbond met ons gesluit. Dit is nie ons voorvaders met wie Hy
hierdie verbond gesluit het nie, maar met ons, ons almal wat nou hier is en nou lewe' (vgl. verder Keller 1971).
God se teenwoordigheid is egter nie toe te skryf aan Israel se verdienste nie. Deuteronomium lê groot nadruk daarop dat Israel God se volk is deur verkiesende liefde (4:37; 7:7; 10:14, $15 ; 14: 2)$. Alhoewel die uittog en woestynreis bewys dat hulle van die begin af hardkoppig en opstandig teen God was, het Hy nogtans sy verbondsbeloftes aan Israel vervul soos Hy aan die aartsvaders beloof het. Hy eis daarom steeds geloof en vertroue in Hom. Aangesien Israel opstandig gebly het, en gevolglik ondergegaan het, moet dit egter steeds gesien word teen die agtergrond van die vrye, onverdiende, verkiesende liefde en die onwrikbare trou van God.

Deuteronomium lê verder nadruk op die innerlike gesindheid as vereiste grondslag van Israel se dade, naamlik liefde, trou, ootmoed en dankbaarheid (6:1-9:6). God roep op tot optrede wat voortkom uit die hele hart en die hele siel. Hierdie oproep rus in God se verbondsverhouding waardeur Hy Hom aan hulle verbind het soos vergestalt word in die Shema wat opgeteken is in 6:4, 5: 'Luister, Israel, die Here is ons God. Hy is die enigste Here. Daarom moet jy die Here jou God liefhê met hart en siel, met al jou krag.' Deuteronomium wil hiermee ' $n$ gesindheid van 'gearriveerdheid' oor die 'erfenis' en die 'verkiesing' by die wortel afsny. In die kern van alles lê steeds 'n persoonlike verhouding tussen God en Israel wat 'n wedersydse gesindheid eis en in 'n daadwerklike optrede 'vandag' tot uiting moet kom: 'Dit is nie ons voorvaders met wie Hy hierdie verbond gesluit het nie, maar ons, ons almal wat hier is en nou lewe' (5:3).

Al bevat Deuteronomium paradoksale uitsprake, is die feitlike boodskap duidelik: dit verkondig geregtigheid (Wetseis) sowel as die onvoorwaardelike verkiesende liefde van God sonder om daarmee ' $n$ dualistiese of teenstrydige benadering te hê (Barrett 2009:94). In 30:1-8 word die motief vir die volk se terugkeer ná straf nie voorgehou as 'n verdienstelikheidsmotief aan die kant van Israel nie. Israel se optrede het immers soveel inherente ongeregtigheid bevat dat dit sou uitloop op hulle ondergang as volk wat tussen die ander nasies in verdrywe is. Die motivering vir Israel se tug en herstel is God self $f^{5}$ en dit word later ook in die geskiedenis van Israel uitdruklik so in die boek Jesaja verkondig (Jes 43:25).

Die onvoltooide lewenstaak van Moses, naamlik dat hy wat Israel uit Egipte gelei het, nie in die beloofde land mag ingaan nie, bewys dat die eis van die Wet vasstaan ondanks die feilbaarheid van die gelowige. Selfs Moses wat die Wet afgekondig het, is voluit daaraan gebind, ten spyte daarvan dat die hardnekkige volk onuitstaanbare druk op hom uitgeoefen het. Verder bewys die beëindiging van sy taak dat, hoe belangrik die land en/of die boodskapper ook al is, dit nie om die land self of die boodskapper gaan nie, maar om God se deurvoering van sy heerskappy volgens sy wil, soos geboekstaaf in sy Wet. Die boek Deuteronomium handel oor die beloofde land, maar dit gaan in wese om 'n woonplek in die vredevolle teenwoordigheid van God, of, beter gestel,

5.Die redding het ook nie ' $n$ mitologiese, historiese, sosio-ekonomiese, militêre, nasionale, geloofs-, of institusionele motief nie, maar is uit en uit teosentries (vgl. Helberg 1990). 
dit gaan om God self en sy teenwoordigheid op alle vlakke van die lewe $(6: 6-9 ; 11: 18-21)$. Deuteronomium fokus dus nie slegs op geestelike en hemelse seëninge nie, maar ook op die konkrete aardse bestaan in 'n persoonlike verhouding met God in al die aspekte van die lewe (Helberg 1990:54).

In verband met die beloofde land sê Deuteronomium dat Israel daar sal woon omdat hulle God se uitverkore volk is ten spyte daarvan dat hulle sonder ware vertroue in God is. Deuteronomium eis dus dat, al is die verbondsvolk ernstig van Jahwe vervreem, hulle Hom in die beloofde land met volle vertroue moet dien omdat Hy die allesbeheersende, regverdige en genadige God is.

\section{Wie in verband met landbesit skuldig is aan geweld}

Volgens Deuteronomium bewoon Israel die land ten koste van die ander nasies en is daarom skuldige bewoners. Presies dieselfde geld ook van die ander nasies, waar hulle ook al woon. Dit word duidelik wanneer daaroor nagedink word dat die Bybel nie skroom om te sê dat die verbondsvolk die land gewelddadig in besit geneem het nie. Ook God was op 'n besondere manier daarby betrokke (2:31-34; 7:1-4; 9:4). ${ }^{6}$

Deuteronomium verkondig dat sowel Israel as die ander nasies verantwoordelik is vir die gewelddadigheid in verband met die verkryging en die bewoning van land. Die geweld wat Israel by die landsverowering gepleeg het, is maar dieselfde as wat die ander nasies gedoen het. Esau se nageslag het byvoorbeeld die Emiete verslaan en uitgeroei (2:10-12). Hierdie soort optrede was volgens die gewoonte van daardie tyd (vgl. ook 2 Kron 20:23). Die feit dat mense oor afgodery en oor buite-egtelike geslagsverkeer met klippe doodgegooi is $(13: 10 ; 17: 5 ; 22: 22,24)$, pas ook in by die harde optredes van daardie tyd (Lundbom 2013:67). Almal was en is slagoffers sowel as plegers van geweld. Niemand kan hulleself verontskuldig en verwyte na ander slinger nie. Land word deur almal ten koste van ander besit.

Wat die ander nasies betref, God laat hulle vernietig omdat hulle goddeloos is (9:4). Hulle bedryf afgodediens, en dit is 'n gruwel in die oë van God. Daarom sal Israel daardie nasies op bevel van God uitdelg (7:24-25). Deuteronomium stel die optrede van God baie radikaal in aansluiting by die radikaliteit van die gevolge van die sonde vanaf die Tuin van Eden en dwarsdeur die geskiedenis.

Die ligpunt is egter God se verhouding met die verbondsvolk en hulle liefdevolle, vrymagtige en genadige verkiesing. So word dit baie sterk in hoofstuk 7 en ook onder andere in 9:4-6 benadruk. Die land is 'n onverdiende geskenk van God aan hulle $(1: 21 ; 4: 1)$, ten spyte daarvan dat hulle die land onwaardig is (9:6). ${ }^{7}$ Die onwaardigheid van die volk is egter

6.Vergelyk ook 2 Kronieke 20:7, 11, 15 in verband met die bedreiging in koning Josafat se tyd.

7.Vergelyk verder die res van die hoofstuk, asook 1:34-36; 4:25-26; 9:22; Waltke (2007:506, 507). nie 'n toestand wat vir God aanvaarbaar is nie. Israel word steeds opgeroep om stiptelik aan Jahwe gehoorsaam te wees en nie ander gode aan te hang nie (9:6). Om egter te voorkom dat hulle ander gode dien, moes die aanhangers van die ander gode uit die land verwyder word, anders sou Israel self ook uit die land verwyder word (11:16-17). In verband hiermee sê Frankel (2011):

All the pentateuchal conquest laws reject the establishment of covenantal alliances with the local inhabitants ... The constraints of maintaining religious purity preclude the possibility of political and social coexistence. By one means or another, the inhabitants must be removed from the land. (pp. 270-276)

Ondanks al die herinneringe en waarskuwings het hardkoppigheid die oorhand oor Israel behou. Teen die einde van die boek Deuteronomium is dit nie meer ' $n$ kwessie van ás hulle ontrou word of ontrou bly nie, maar die feit dát hulle God sal verlaat, ander gode in die land sal dien en te gronde sal gaan (31:16-22). Daaroor moet Moses 'n lied opteken waarin veral God se grootheid, regverdigheid en betroubaarheid, in antitese met Israel se optrede, besing word (32:1-4). Hy straf die nasies, wreek die bloed van sy dienaars en bring vrede tussen Hom en sy land, tussen Hom en sy volk (32:36-43). Voor Moses sterf, seën hy die volk deur Jahwe as ewige God en skuilplek aan hulle voor te hou en Israel as ' $n$ volk wat deur God verlos is $(33: 1-3,29)$. Hy sou uiteindelik tog red en dit het reeds alles by Hom vasgestaan. Deuteronomium benadruk dus dat God die onmoontlike doen.

God se wonderdadige optrede geld ook in verband met sy aanspreeklikheid vir wat Hy in 'n sondige, stukkende wêreld doen. Dit is die wonder van sy verlossingswerk dat Hy selfs déúr die sondige optrede van sy volk en van ander volke héén werk, nie bloot daaromheen nie. Niks gebeur buite sy optrede, mag en wil nie, ook nie die geweld wat mense as negatief beskou nie. God se betrokkenheid by die gewelddadigheid in die inbesitneming van die land moet ook in daardie lig beoordeel word, naamlik dat Hy daardeur verlossing bewerk.

God se wonderdadige optrede blyk verder daaruit dat Hy sy eie optrede verander en later met Israel 'n nuwe verbond sluit. Daarin bewerk Hy self die verlangde gehoorsaamheid aan sy Wet en wil in hulle (Jer 31:31-34; Eseg 11:16-20). Om dit te kan doen gaan die Woord anders werk. Hy sal as ' $t$ ware 'n opstandingslewe bewerk, lewe uit dood. Die verbond waarvan die bepalings duidelik in Deuteronomium uitgeteken is - bly voortbestaan, maar word 'herskep'.

Die vraag kan gevra word of dit billik is dat Israel die besonder genadige hantering van God ontvang terwyl die ander nasies hoofsaaklik sy toorn ontvang. Is God nie onregverdig nie? Die bespreking hierbo het reeds gewys dat God se eise billik is. Die ander nasies kan God nie verwyt nie, aangesien hulle self mekaar lyding aandoen. Volgens Deuteronomium misluk alle mense in hierdie wêreld, ook Israel en selfs Moses faal (3:23-26). Teen die agtergrond van hierdie gegewens gesien, is sy optrede dus billik. 
In werklikheid kan God se optrede eintlik nie deur die mens beoordeel word nie, omdat daar soveel vervreemding tussen God en mens gekom het. Wat in wese moet gebeur, is dat God se optrede fyn deur die mens waargeneem moet word ter wille van die openbaringskarakter wat daarin geleë is. So word Hy geken uit die waarneming van sy optrede en die antwoorde wat Hy self gee. Wanneer die nasies byvoorbeeld sal vra (24-27): 'Waarom het die Here dit met hierdie land gedoen?' sal die antwoord wees: 'Omdat die mense van hierdie land die verbond gebreek het ... daarom het sy toorn ontvlam.'

Dit is egter nie net die toorn van God wat in sy optrede openbaar word nie, maar ook sy liefde en genade as teenpool van sy toorn. Die oplossing wat God gee om te voorkom dat alle mense onder sy toorn vergaan, is ' $n$ wonder, soortgelyk aan die Goddelike geduld wat Israel dwarsdeur ondergang vashou en dra. Daar sou egter selfs meer plaasvind soos later in Jesaja uitgespel word. Die 'onlogiese' sou gebeur, naamlik dat God die verantwoordelikheid vir die mens se mislukking op homself neem. In verband hiermee sê Deuteronomium 30:

$\mathrm{Al}$ is jy verdryf tot in die uithoeke van die aarde, die Here jou God sal jou daar gaan bymekaarmaak en van daar af gaan haal. Hy sal jou terugbring na die land toe wat deur jou voorvaders besit is en jy sal dit in besit neem. (v. 4, 5)

\section{Gelykluidend hieraan sê Jesaja 43:}

Moenie bang wees nie, Ek is by jou. Ek bring jou kinders van die ooste af, Ek maak hulle bymekaar van die weste af, Ek sê vir die noorde: Gee! Vir die suide: Moet hulle nie terughou nie! Bring my seuns van ver af, my dogters van die uithoeke van die aarde af, elkeen wat na my Naam genoem word, elkeen wat Ek geskep het tot my eer, wat Ek gevorm het, wat Ek gemaak het. Laat my volk hierheen kom. (v. 5-8)

\section{Wat God in verband met die verantwoordelikheid doen}

Soos reeds gesien, het land in die Ou Testament ' $n$ wesenlike plek in die bestaan van Israel en die hele mensdom. In hierdie hoofpunt word enkele sake weer aangeraak om die onderwerp verder te belig en die aandag op enkele ander sake wat daarmee verband hou, te vestig.

Land skadu iets van die verlore Tuin van Eden af, naamlik die verlies van 'n lewe in die besondere teenwoordigheid van God (Gen 3:24; 12:1-3). Die mensdom verkeer weens sy hubris [hoogmoed] in 'n stryd met die aarde en met mekaar (Gen 3-4). Liggaamlike, stoflike en geestelike disintegrering is daarom deel van die menslike bestaan en is tegelykertyd straf van God. Daarvoor kan die mensdom net hulleself verwyt. Hulle voer die paradoksale bestaan van onder die straf van God en terselfdertyd onder sy genade en beskerming te wees (Gen 4-5; vgl. Ps 90:1-3, 7-11, 12-17). Waar die mens hom ook al sal vestig, is hy 'n vreemdeling sonder regte, want landsbesit sonder God bring nie vrede nie.

Dit is alleen wanneer God vir die mens 'n bestaanruimte aanwys, dat die mens hom vreedsaam daar kan vestig.
Selfs dan is sy bestaan nog gebroke, soos by Israel se vestiging in die beloofde land. Die mensdom het die 'reg' op landsbewoning verloor en daarom is dit ook onmoontlik om onderling in vrede te woon. Die mensdom tree gewelddadig op in verband met die verkryging sowel as bewoning van 'n land (en enige woonplek). Hulle woon ten koste van ander.

Net soos in die Tuin van Eden, het God die opstandige mens tog nie heeltemal verlaat nie, maar bewys Hy steeds genade teenoor die mens. Selfs al wil hy God ontvlug, bly God na hom roep, soos in die Tuin van Eden. Dit het Hy in Abram, later Abraham, gestalte laat kry toe die mensdom die rug op Hom gekeer het (Gen 11-12). Enersyds maak Hy 'n breuk met die mensdom, andersyds wys Hy dat Hy sy koninkryksheerskappy laat voortgaan, onverdiend, wonderdadig, in 'n oorblyfsel in 'n land wat Hy aan Abram beloof het. Omdat God só teenoor Abraham optree, is dit tegelykertyd 'n aanduiding dat daar vir ander ook so 'n moontlikheid bestaan. Die roeping van Abram gaan trouens gepaard met die belofte dat al die nasies in hom geseën sal word (12:1-3).

Behalwe dat landsbesit iets van die Tuin van Eden vergestalt, vergestalt dit ook die mensdom se onbekeerlike miskenning van God en daarmee saam hulle miskenning van ander mense se aanspraak op die land. Dit is die situasie soos dit duidelik geillustreer word by Israel se intog in die beloofde land. Wat kan van so iets word? Is daar enige moontlikheid van 'n oplossing? Een saak is duidelik: wat die nasies se eie bedoeling met en miskenning van Hom ook al was, dit is Hy wat vir hulle 'n bestaansruimte afgebaken het (32:8). Hy is oral konkreet betrokke, selfs teen sy eintlike wil. ${ }^{8}$ Deuteronomium verkondig God se absolute heerskappy, selfs oor optrede wat Hom nie erken nie of wat teen Hom en sy heerskappy gekant is. Wright (1953) oordeel soos volg:

God exercises his judgement in history chiefly by chosen human agents, in this case the agent is Israel, just as in later times a foreign power was his agent of judgment on Israel herself. The agent is not used for its merit but solely because God has chosen to accomplish his ends in history by mediate (i.e. human) means. (p. 327)

Dit is in die lig hiervan dat God se betrokkenheid by gewelddadigheid ten opsigte van die beloofde land bekyk moet word. Dit gaan om volledige heerskappy, volledige wil en emosie, volledige geregtigheid, die eis om volledige betrokkenheid, soos dat die mens volledig in liefde met hart en siel betrokke moet wees, en volledige gehoorsaamheid aan sy gebooie. Dit is die wonderweg van die paradoksale menslike bestaan in 'n disintegrerende wêreld onder God se straffende en tegelyk genadige heerskappy.

Hoe onbegryplik hierdie werklikheid ook al is, nog onbegrypliker is die werklikheid wat implisiet in Deuteronomium gestel en duidelik deur Jesaja verkondig word, naamlik dat God die verantwoordelikheid en skuld op Homself neem. Hierdie feit lê daarin opgesluit dat dit Hý is

8.Vergelyk Klaagliedere 3:31-33 vir optrede teen sy wil. 
wat aan Israel die opdrag gee om gewelddadig teenoor die nasies op te tree. Ondanks hierdie opdrag is Hy nie daarvoor toerekenbaar nie, aangesien dit die nasies se verdiende straf is en hulle volgens intydse gebruik self ook so onder mekaar opgetree het. Israel is in hierdie opdrag in 'n uitsonderlike posisie. Hierdie posisie is die vrug van die Goddelike uitverkiesing sonder menslike verdienste. Dit hou egter verantwoordelikheid asook die eis om te verander by hulle en ook by andere in: om volgens die wil/Wet van God te lewe. Dit impliseer 'n Goddelike wonder waarin die hart verander word om God en die naaste, selfs ook die vreemdeling, lief te hê $(10: 19)$.

Deuteronomium benadruk God se absolute heerskappy in so 'n mate dat dit onbegryplik is en selfs teenstrydig lyk met sy Goddelike aard en met sy benadering van die mens en sy verlossing. Dit is egter in hierdie boek waarin God se optrede teen die menslike sonde en onbekeerlikheid dikwels en kras beskryf word, dat Hy die verantwoordelikheid vir die mens se onbekeerlikheid op Hom neem. Hierdie boek wat mense aanstoot gee oor God se betrokkenheid by gewelddadigheid in verband met land, gee lig in die aardse werklikheid. Die boek sê die oplossing kan net van God se onverdiende genade en liefde kom en moet menslike liefde vir en gehoorsaamheid aan Hom as vrug hê. Dit geld uiteindelik ook vir die ander nasies. Hulle sal in hierdie seën van God deel.

\section{Wat Jahwe se optrede vir die nasies inhou}

Moses was in sy tyd 'n unieke profeet in Israel (34:10), maar daar is aan Israel ook 'n profeet soos Moses belowe vir wie Jahwe sy woorde in die mond sal lê $(18: 15,18)$. Daar is 'n noue verband tussen die verkondiging van Moses en dié van die profete wat veel later opgetree het. So is daar byvoorbeeld 'n ooreenkoms in Deuteronomium se verkondiging oor Moses en dié van die profeet Jesaja oor die lydende dienaar van Jahwe. Wright (1953) sê:

only Moses as a suffering servant, making intercession for his people and bearing their sins, had averted God's just wrath. It was for their sins therefore, that Moses was not allowed to enter the promised land $(1: 37 ; 3: 26 ; 4: 21 ; 9: 18-20,25-29 ; 10: 10)$. (p. 327)

Die verkondiging van God se absolute heerskappy, sy verkiesende genade en verbondstrou, en dat Hy die verantwoordelikheid van skuld op Hom neem, word nog duideliker deur die profeet Jesaja gestel. Jesaja se vroeë verkondiging (1-39) weerklink in 'n tyd wat dit lyk of Israel as volk tot sterwe sal kom. Hy verkondig dat die volk weggevoer sal word uit die beloofde land, onder heerskappy van 'n heidense nasie wie se gode vir hulle oorwinning oor die verbondsvolk geprys sal word (Jes 39:6). Nadat hierdie profesie vervul is, is Israel in Babel spottend gevra om Sionsliedere oor die onoorwinlikheid van sy God te sing, maar Israel kon net swyg (Ps 137). Juis in hierdie tyd gee die profesie van Jesaja perspektief. Téén die werklikheid van hierdie troostelose toestand ín, verkondig die tweede deel van Jesaja (40-66) die grootheid, almag en wysheid van God. Jesaja sê hierin dat God 'n doel het met die skynbare ondergang van Israel en die skynbare onmag of onbetrokkenheid van God by wat gebeur. God maak dat Israel se lyding nie net die gevolg van sonde is nie, maar ook 'n middel tot ' $n$ doel. Die doel is dat hulle die lig vir die nasies sal wees deur die Wet en wil van God vir hulle te leer (42:6; 49:6). In plaas daarvan dat Israel se oënskynlik ondergang 'n bewys van God se onmag is, is dit eerder die bewys van sy regverdige en onpeilbare regering en redding vir Israel en die nasies (Jes 60:1-3; Van der Walt 2014).

In sowel Deuteronomium as Jesaja is daar krasse geweld, maar ook oorweldigende liefde, soos gesien in die uitverkiesing van 'n sondige en halsstarrige volk in Deuteronomium en in die intense, pynlike straf, gepaard met medelye in Jesaja 1:2-9.

Jesaja kondig aan dat God Israel uit ballingskap sal lei (40:1-11). Al die onoorkomelike hindernisse sal uit die weg geruim word, en God sal self deur sy besondere teenwoordigheid die oorwinning bring. Sy groot mag gaan gepaard met deernisvolle herderlike sorg vir sy volk (40:9-11). So word die belofte oor die land in stand gehou en die lewewekkende krag van die Woord en die getrouheid van God aan sy beloftes, geopenbaar (40:1-5). Dit gebeur nie net vir sy volk nie, maar ook tot voordeel van die mensdom. Albei groepe is deur ongehoorsaamheid teenoor die Woord en wil van God soos gras wat deur die dorre wind vergaan. Dieselfde Woord bring egter uiteindelik die ware lewe vir beide $(40: 8 b)$.

In Jesaja 40:12-31 word 'n herhalende retoriese vraag aangetref wat ingelei word met: 'Wie het ...?' Hiermee word God se onvergelyklike, ondeurgrondelike skeppersen regeerdersmag, betrokkenheid, wysheid en deernis aan Israel voorgehou. Die volgende paar aanhalings uit Deutoronomium 40 laat iets van die kragtige verkondiging hoor:

Wie het die waters in die holte van sy hand afgemeet? Wie kan die Gees van die Here peil, wie kan sy raadgewer wees? ... Met wie kan julle God dan vergelyk? Met watter beeld kan julle Hom gelykstel? ... Waarom sê jy dan Jakob/Israel: Die Here sien nie raak wat van my word nie, my reg gaan by my God verby? ... Hy gee die vermoeides krag, Hy versterk dié wat nie meer kan nie. Selfs jongmanne word moeg en raak afgemat ... maar dié wat op die Here vertrou, kry nuwe krag. Hulle vlieg met arendsvlerke, hulle hardloop en word nie moeg nie, hulle loop en raak nie afgemat nie. (v. 13, 18, 27, 29-31)

Omdat God is soos Hy hierbo verkondig word, kan die sogenaamde Dienaarliedere wat in Jesaja voorkom, verkondig dat die dienaar van Jahwe nie alleen vir Israel instaan nie, maar dat hy/Hy 'n lig vir die nasies is. In Jesaja 42:6 en 49:6 word die dienaar gesien as Israel, die profeet, maar tegelyk ook iemand meer as die profeet en as Israel wat die ongelooflike doen: as onaansienlike laat hy die mag van Jahwe sigbaar word deur 'ons' straf en lyding op Hom te neem. Plaasbekledend vir ons, word Hy geweldadig, soos in

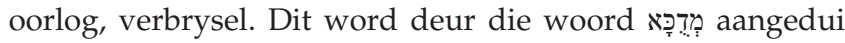


wat in die $p u^{\prime} a l$-vorm staan. Daaruit word dit duidelik dat die kneg op die ergste wyse geestelike en fisiese verbryseling ondergaan het (Domeris 1998:943). Hy sterwe, maar nogtans lewe hy (Jes 53:1-10). In hom/Hom kom die seën vir die nasies tot vervulling, die seën wat by die roeping en afsondering van Abraham beloof is (Waltke 2007:845).

Jahwe se optrede bring dus sinvolheid vir Israel en is ook tot voordeel van die nasies. Die sinvolheid word egter nie noodwendig deur die mens ingesien nie. So het Israel die optrede van God in die ballingskap bevraagteken. Hierdie bevraagtekening was die gevolg daarvan dat daar slegs na die gebeure gekyk is, sonder om die verduideliking van die gebeure in ag te neem. Deur bloot die ballingskapsgebeure waar te neem het die volk enersyds gevra na God se bereidheid om te red (Jes 40:27) en andersyds na sy vermoë om te red (59:1). Dit was eers toe Jesaja se profetiese verkondiging die regte perspektief op God se optrede in die ballingskap gegee het, dat die volk insig kon kry en die regte gevolgtrekkings kon maak. Toe het die besef deurgedring dat die oorsaak van die ballingskap nie by Jahwe lê nie, maar by die mens. Die besef het egter ook deurgedring dat die oplossings nie by die mens lê nie, maar by God (Van der Walt 2014). Soortgelyk aan die perspektief wat Jesaja in verband met die ballingskap gegee het, gee Deuteronomium ook in verband met die geweld tydens die besetting van die beloofde land (Brueggemann 2003:92). Indien daar slegs na die geweld gekyk word, is daar nie volledige perspektief nie. Indien Deuteronomium se verkondiging oor God se volledige betrokkenheid in dood en lewe egter gehoor en internaliseer word, kom daar begrip oor Wie God is:

Besef dit tog: Ek, Ek is die Here! Naas My is daar geen ander God nie. Ek maak dood en Ek gee lewe. Ek maak siek en Ek maak gesond. Uit my mag word niemand bevry nie. (32:39)

\section{Samevatting en gevolgtrekking}

God is volgens Deuteronomium aktief betrokke by gewelddadige inbesitneming van die beloofde land. Hy laat Israel die beloofde land met geweld en uitroeiing van die bevolkings in besit neem. Selfs teenoor Israel tree Hy egter ook gewelddadig op met straf.

Nóg die nasies nóg Israel kan God egter daaroor verwyt, want hulle tree self gewelddadig en eksploiterend op. Hulle bewoon die aarde ten koste van ander en ten koste van die aarde. Hulle is self die oorsaak van lyding. Wanneer lyding op aarde ter sprake is, moet die erns van die sonde benadruk word. Dit is deel van die mens se kultuur om hardnekkig op te tree teen die Wet en wil van God wat die beste vir hom bedoel. God is in die stukkende, sondige wêreld in beheer van alles wat gebeur, maar Hy doen dit onbegryplik en wonderdadig. Hy werk in en deur die sondige werklikheid, maar die verkeerde bedoeling en optrede is dié van die mens.

Deur aan Israel die opdrag te gee om geweld teenoor sy vyande te gebruik, tree God plaasvervangend vir Israel se optrede op, en daarmee uiteindelik ook vir die ander volke. Hy staan in vir die sondige mens wat hom teen Hom verset asof Hy die oorsaak van die lyding is en daarvoor aanspreeklik is. Deuteronomium verkondig in hierdie opsig implisiet dieselfde as wat die Dienaarliedere in Jesaja pertinent verkondig. Die verkondiging van Deuteronomium en Jesaja adem dieselfde atmosfeer van krasse geweld én oorweldigende liefde, van vernietigende straf gepaard met medelye. Jesaja gaan nog verder en laat die onverwagte en wonderlike lig skyn van die Dienaar se onbegryplike lyding ter wille van ander. Daarin word God se genade en geduld asook sy geregtigheid en afsku van onreg openbaar. Dit is in die lig van hierdie positiewe optrede van God wat sy optrede waardeer moet word. Dit moet ook daartoe lei dat sy optrede as 'anders' maar sinvol gesien word. In die lig hiervan moet daar dus nie net in die nadenke oor geweld in die $\mathrm{Ou}$ Testament teen die teks vasgekyk word nie, maar verder na God wie se werk en optrede in die teks beskryf word. Daar moet nie net na die geweld waarby God betrokke is gekyk word nie, maar ook na die verlossing wat daardeur bewerk word.

Hierdie optrede van God handhaaf ook die oproep tot die mens om sy verantwoordelikheid, wat in ooreenstemming is met dié van God, na te kom; nie net teenoor Hóm nie, maar ook teenoor die bestaansruimte wat God hom gun en teenoor diegene met wie daardie bestaansruimte gedeel word. In hierdie opsig word die Ou-Testamentiese teks dus nie net gesien as een wat geweld bevorder nie, maar ook as 'n teks wat die leser oproep tot die weerspieëling van God se optrede waar Hy geweld op Homself keer ter wille van die mens se voortbestaan.

Die gevolgtrekking waartoe daar dus gekom word, is dat die Ou Testament ' $n$ boek vol geweld is, maar dat dit nie sinnelose geweld is nie, maar eerder deel van die geboorteproses van 'n nuwe begin wat deur dieselfde God (wat van slegs van geweld beskuldig word) moontlik gemaak word.

Die verantwoordelike lees daarvan waarvoor Meyer (2011) vra, lê dus nie in die teks nie, maar in God van wie die teks getuig. Dit is sy volle optrede van geregtigheid maar ook selfopoffering wat weerspieël moet word in die SuidAfrikaanse identiteit sodat geweld nie die antwoord op oorlewing is nie.

\section{Erkenning Mededingende belange}

Die outeurs verklaar dat hulle geen finansiële of persoonlike verbintenis met enige party het wat hulle nadelig of voordelig kon beïnvloed het in die skryf van hierdie artikel nie.

\section{Outeursbydrae}

Beide outeurs, J.L.H. (Noordwes-Universiteit) en C.v.d.W. (Noordwes-Universiteit) het gelyke bydraes gelewer tot die navorsing en skryf van hierdie artikel. 


\section{Literatuurverwysings}

Barrett, R., 2009, Disloyalty and destruction: Religion and politics in Deuteronomy and the modern world, T\&T Clark, New York.

Brueggemann, W., 2003, An introduction to the Old Testament: The Canon and Christian imagination, Westminster John Knox Press, Louisville.

Clements, R.E., 2001, The book of Deuteronomy: A preacher's commentary, Epworth Press, Peterborough.

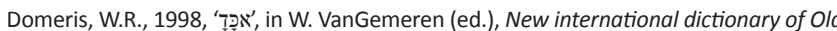
Testament theology and exegesis, vol. 1, pp. 943-946, Zondervan, Grand Rapids.

Fee, G.D. \& Hubbard, R.L., 2011, The Eerdmans companion to the Bible, Eerdmans, Grand Rapids.

Firth, D.G. \& Johnston, P.S. (eds.), 2012, Interpreting Deuteronomy: Issues and approaches, Apollos, Nottingham.

Frankel, D., 2011, The land of Canaan and the destiny of Israel: Theologies of territory in the Hebrew Bible, Eisenbrauns, Winona Lake.

Gordon, R.P., 1998, 'אָרָר', in W. VanGemeren (ed.), New international dictionary of Old Testament theology and exegesis, vol. 1, pp. 524-526, Zondervan, Grand Rapids.

Helberg, J.L., 1990, Die Verbondsvolk se verhouding tot sy land: Veral in die tyd rondom die wegvoering in Babiloniese ballingskap: Die Groot Profete en Klaagliedere, Departement Sentrale Publikasies, PU vir CHO, Potchefstroom.

Helberg, J.L., 2011, Die Here regeer: Openbaringslyn deur die Ou Testament, V\&R Drukkery, Pretoria.

Karimi, F., 2015, What's behind xenophobic attacks in South Africa, viewed 20 April 2015 from http://edition.cnn.com/2015/04/18/africa/south-africa-xenophobia-explainer/
Keller, C.A., 1971, 'rr verfluchen', in E. Jenni \& C. Westermann (eds.), Theologisches Handwörterbuch zum Alten Testament, vol. 1, pp. 236-240, Chr. Kaiser Verlag, München.

Longman, T. \& Dillard, R.B., 2010, An introduction to the Old Testament, 2nd edn., Apollos, London.

Lundbom, J.R., 2013, Deuteronomy: A commentary, Eerdmans, Grand Rapids.

McConville, G.J., 1998, 'רִִִּ ', in W. VanGemeren (ed.), New international dictionary of Old Testament theology \& exegesis, vol. 1, pp. 747-755, Zondervan, Grand Rapids.

Meyer, E.E., 2011, 'The role of the Old Testament in a violent world', Verbum et Ecclesia 32(2), Art. \#502, 8 pages. http://dx.doi.org/10.4102/ve.v32i2.502

Miller, P.D. Jr., 1986, Interpreting the Psalms, Fortress, Philadelphia.

Van der Walt, C., 2014, 'The deaf cannot see: An accumulation of blindness and deafness as combined theme in Isaiah 42 and $43^{\prime}$, In die Skriflig/In Luce Verb 48(2), Art. \#1764, 6 pages. http://dx.doi.org/10.4102/ids.v48i2.1764

Vannoy, J.R., 1988, 'Land', in W.A. Elwell \& B.J. Beitzel (eds.), Baker encyclopedia of the Bible, pp. 1305-1307, Baker, Grand Rapids.

Von Rad, G., 1962, Old Testament theology, vol. 1, Oliver \& Boyd, Edinburgh.

Von Rad, G., 1968, Das fünfte Buch Mose: Deuteronomium, Vandenhoeck \& Ruprecht, Göttingen. (Das Alte Testament Deutsch).

Waltke, B.K., 2007, An Old Testament theology: An exegetical, canonical, and thematic approach, Zondervan, Grand Rapids.

Wright, G.E., 1953, 'Deuteronomy', in The Interpreter's Bible, vol. 2, pp. 309-537, Abingdon Press, New York. 